\title{
Roman law in the period of profound changes in Polish science*
}

\section{INTRODUCTION}

The civil law tradition is a way of thinking about private law. It manifests itself in the discussion conducted over centuries under the influence of Roman law. Polish legal culture became a part of this legal tradition completely in the $19^{\text {th }}$ century. ${ }^{1}$ When Poland regained its independence in 1918, it did not lead to doubts regarding the future development of Polish private law in the manner which is typical for the civil law tradition. ${ }^{2}$ However from the beginning of $20^{\text {th }}$ century, the science of Roman law is decisively separated from the theory and practice of applicable private law. This division inspires the questions pertaining to the meaning, aims, and methods of researching Roman law in Poland as well. The general image of the Roman law studies in Poland is represented by its bibliography. They provide a basis for a quantitative evaluation. They sometimes present general evaluations based on the quantitative criterion. Moreover, from the middle of the last century there are published papers with the aim to present a synthetic representation and evaluation of the research into Roman law in Poland. The num-

* I'm grateful to Paul Du Plessis for helpful remaks on this topic. I'm also appreciate the reviewers' comments.

1 J. Kodrębski, Prawo rzymskie w Polsce $w$ XIX w. [Roman law in Poland in the $19^{\text {th }}$ century], Łódź 1990, p. 258.

${ }^{2}$ F. Longchamps de Bérier, Stałość a zmienność szczegółowych regulacji prawa spadkowego Niepodległej [Constancy and Changes of Succession Regulations in 100 Years of Poland's Independence], "Forum Prawnicze" [Legal Forum], 2018, Vol. 46, issue 2, pp. 4-5; W. Dajczak, Die Privatrechtsentwicklung in Polen nach 1918, "Zeitschrift für Neuere Rechtsgeschichte" 2019, Vol. 41, issues 1-2, pp. 54-55. 
ber of such publications has risen significantly in the first two decades of the $21^{\text {st }}$ century. The discussion pertaining to the research and teaching Roman law in Poland is livelier in the last decade. It is also accompanied by the profound changes in the organization of the Polish higher education system and in the financing of science which have been introduced since 2010. The latest element in this process of change was the Higher Education and Science Act enacted on the $20^{\text {th }}$ of July 2018. Deeply neoliberal changes are described as a field of conflict between global processes and the local academic tradition which is restrained towards change. ${ }^{3}$ The changes introduced in 2018 stretched the significance of the role of bibliometric criteria also to the evaluation of the field of law. This change raises doubts. ${ }^{4}$ However, it cannot be omitted when the issues of the current state as well as of the future of teaching and research of Roman law in Poland are raised. The current changes can be confronted with the traditional style of publishing regarding Roman law, understanding of the internalization of the research in Roman law, and the premise of its endurance in Poland. Language is a serious barrier impeding the acquisition of bibliographic information pertaining to Polish research into Roman law. Furthermore, the majority of evaluation papers of these researches were published in Polish. ${ }^{5}$ Consequently, the paper begins with a short presentation of these elements of the debate about Roman law in Poland.

\section{BIBLIOGRAPHIES OF OF ROMAN LAW IN POLAND}

The first bibliography of the more important Polish works on Roman law was published in Italian by Rafał Taubenschlag in $1936 .{ }^{6}$ This fragmentary rep-

${ }^{3}$ D. Antonowicz, Między siła globalnych procesów a lokalna tradycją. Polskie szkolnictwo wyższe $w$ dobie przemian [Between the power of global processes and local tradition. Higher education in Poland in the time of change], Torun 2015, p. 358.

${ }^{4}$ W. Dajczak, Ein neues Recht für die Wissenschaft in Polen, "Forschung \& Lehre" 2019, No. 12, pp. 1100-1102.

${ }^{5}$ Evaluations of Polish studies on Roman law in foreign languages are made by: H. Kupiszewski, Droit romain - science et didactique [in:] W. Wołodkiewicz, M. Zabłocka (eds.), Le droit romain et le monde contemporain, Warsaw 1996, pp. 163-173; M. Kuryłowicz, Aufstieg oder Niedergang? Zur gegenwärtigten Bedeutung des römischen Rechts in Polen [in:] W. Wołodkiewicz, M. Zabłocka (eds.), Le droit romain..., pp. 175-181; W. Wołodkiewicz, Il diritto romano esistera ancora? A margine di nuovi disegni di riforma degli studi giuridici in Polonia, "Iura" 2014, No. 62, pp. 159-169; M. Zabłocka, La romanistica polacca del XXI secolo [in:] I. Piro (ed.), Scritti per Alessandro Corbino, Tricase 2016, pp. 567-588; W. Dajczak, Diritto romano in Polonia dopo il 1989: fra identità giuridico-culturale ed europeizzazione della ricercha del diritto privato [in:] L. Vacca (ed.), Nel mondo del diritto romano. Convegno ARISTEC, Roma 10-11 ottobre 2014, Naples 2017, pp. 215-228.

${ }^{6}$ R. Taubenschlag, Gli studi di diritto romano in Polonia nel secolo XX [in:] Gli Studi Romani nel mondo, vol. 3, Bologna 1936, pp. 247-268. 
resentation of Polish publications on Roman law was supplemented by later bibliographies in Polish. Juliusz Wisłocki published a register of papers which pertained to Roman law and were written in Poland between the late Middle Ages and $1945 .^{7}$ The bibliography concerning the period between 1918 and 1945 has been supplemented recently. ${ }^{8}$ The following short bibliographies in foreign languages of Polish works on Roman law were published in the seventies of the last century. ${ }^{9}$ The first comprehensive bibliography of such works was published in German by Janusz Sondel. ${ }^{10}$ Sondel's bibliography was further developed in Polish by Maria Zabłocka and she updates it regularly. The bibliography published in the beginning of the $21^{\text {st }}$ century retained the taxonomy adopted by Sondel. ${ }^{11}$ The publications within are collected in fourteen sections: general papers, handbooks and textbooks; auxiliary publications; the history of sources; civil procedure; personal law and legal transactions; family law; rights in rem; obligations; inheritance law; criminal law; public law; philosophy of law, methodology, and political and legal doctrines; the significance of Roman law and the evaluation of the Romanists' output. This classification was supplemented in the bibliography published in the beginning of the second decade of the $21^{\text {st }}$ century with the following sections: other ancient laws; Roman law in Europe after Justinian; the significance of Roman law to the present day; Polish Romanists in the literature of recent years. The bibliography was also supplemented with personnel data, information pertaining to the international cooperation of Polish Romanists as well as information pertaining to the conferences and meetings they had organized. ${ }^{12}$ In the last published bibliography, these changes were further developed by replacing the "Polish Romanists in the literature from recent years" section with two new sections: "papers on the history of Chairs of

7 J. Wisłocki, Dzieje nauki prawa rzymskiego w Polsce [The History of the science of Roman law in Poland], Warsaw 1945. He divided it into 267 biographical records. He also distinguished 643 bibliographical positions in it.

${ }^{8}$ K. Szczygielski, Romanistyka polska w latach 1918-1945 (przeglad bibliografii) [Roman law studies in Poland between 1918 and 1945 (a review of bibliography)], "Zeszyty Prawnicze UKSW" 2010, No. 2, pp. 355-409.

9 A. Wiliński, Rapporto bibliografico (Polonia) per gli anni 1967-1969, "Index" 1972, No. 3, pp. 86-105; idem, Rapporto bibliografico (Polonia) per gli anni 1970-1974, "Index" 1976, No. 6, pp. 323-348.

$10 \mathrm{~J}$. Sondel, Polnische Romanistik in den vergangenen fünfunddreißig Jahren. Abriß einer Bibliographie, "Zeszyty Naukowe Uniwersytetu Jagiellońskiego. Prace Prawnicze” 1980, No. 86, pp. 133-168.

${ }_{11}$ M. Zabłocka, Romanistyka polska po II wojnie światowej [Roman law studies in Poland after World War II], Warsaw 2002, p. 10.

${ }_{12}$ M. Zabłocka, Romanistyka polska w pierwszym dziesięcioleciu XXI wieku [Roman law studies in Poland in the first decade of the $21^{\text {st }}$ century], Warsaw 2013. 
Roman law" and "Romanists' profiles."13 These changes in the classification of the publications reflect three tendencies in the the activity of employees of the Chairs or Departments of Roman Law in Poland in the last 20 years. Firstly, an increase in the number of publications on antiquity devoted to law by historians as well as the greater interest of certain legal historians in legal papyrology and other ancient laws besides Roman ones. ${ }^{14}$ Secondly, an increase in the number of publications devoted to the role of Roman law from the Middle Ages until the present day. ${ }^{15}$ Thirdly, a clearly rising number of publications presenting who has taught Roman law and how it has been researched in Poland. ${ }^{16}$ Successive authors employed a similar type of classification of Polish papers on Roman law and it gives a clear basis for determining trends in the bibliography based on a quantitative criterion. For instance, in 2013, this was the grounds to claim that: "civil procedure, like up till now, does not command great interest," 17 "obligations do not constitute, like in the previous century, a central field of interest of Polish Romanists," 18 the number of publications on public law is equal to the number of publications on the entire private law since the beginning of the $21^{\text {st }}$ century. ${ }^{19}$ According to similar evaluations from 2017, it was pointed out that: "civil procedure has been of relatively large interest recently;" 20 "In the past three years, just like in the one before that, the interest in the law of obligations has decreased and there has been a commensurate increase in the number of publications in the field of criminal law and public law;" "21 "inheritance law has recently enjoyed exceptionally large interest." ${ }^{22}$ The publications on private law, placed in the traditional sections of Roman law bibliography, increasingly frequently combine ancient Roman law with a historical and comparative analysis directed towards modernity. ${ }^{23}$ These evaluations and the changes in the structure

${ }^{13}$ M. Zabłocka, Gorsze lata polskiej romanistyki [Worse years of Roman law studies in Poland], „Zeszyty Prawnicze UKSW” 2017, No. 4, pp. 132-177.

${ }_{14}$ M. Zabłocka, Romanistyka polska w pierwszym... [Roman law studies in Poland in the first...], pp. 113-120; eadem, Gorsze lata... [Worse years...], pp. 160-162.

${ }^{15}$ M. Zabłocka, Romanistyka polska w pierwszym..." [Roman law studies in Poland in the first...], pp. 121-153; eadem, Gorsze lata... [Worse years...], pp. 162-171.

${ }^{16}$ M. Zabłocka, Romanistyka polska $w$ pierwszym... [Roman law studies in Poland in the first...], pp. 155-164; eadem, Gorsze lata... [Worse years...], pp. 171-176.

${ }^{17}$ M. Zabłocka, Romanistyka polska w pierwszym... [Roman law studies in Poland in the first...], p. 35 .

${ }^{18}$ Ibidem, p. 61.

19 Ibidem, p. 93.

${ }^{20}$ M. Zabłocka, Gorsze lata... [Worse years...], p. 138.

${ }^{21}$ Ibidem, p. 144.

22 Ibidem, p. 147.

${ }^{23}$ E.g.: J. Rudnicki, Testament żolnierski i testamenty wojskowe w europejskiej tradycji praw$n e j$ [Soldier's will and military wills in European legal tradition], Bielsko-Biała 2015; B.J. Kowal- 
of the bibliography show continuity and changes in the subjects undertaken by Polish authors. Whoever wishes to find the most up-to-date bibliography of Polish publications on Roman law can obtain a list from the Internet nowadays. It is updated courtesy of the Chair of Roman and Antique Law at the University of Warsaw. ${ }^{24}$

\section{STATEMENTS EXPRESSING HOW THE ROMAN LAW STUDIES SHOULD BE CONDUCTED IN POLAND}

Publishing bibliographies and evaluations of the Roman law studies in Poland is accompanied by forming propositions concerning what should be most important in these studies or what should be changed in them. Just in the first year of Polish independence regained in November 1918, Stanisław Wróblewski, ${ }^{25}$ a pre-eminent professor of Roman and private law in Cracow, said that he "does not think that Poland [...] is a suitable area to conduct such intense studies of Roman law like Germany for a long time and like Italy in the last few decades." ${ }^{26} \mathrm{He}$ stated that he imagined the development of Roman law studies in Poland should be "generally similar" to the ones conducted in France. ${ }^{27} \mathrm{He}$ indicated that the history of Roman law in Poland was the only field of Roman law science which should be studied in detail and he considered it to be a duty of Polish science. ${ }^{28}$ Furthermore, it was Wróblewski's opinion that not all main fields of the research of Roman law, which he called interpolating and papyrological, should be developed at every Polish university. He acknowledged the rationality of the decision made by the respective universities which pertained to choosing which area of Roman law studies they wanted to support and develop. Moreover, he emphasized that supporting Roman law studies should be consistent with the rationality of financing research. ${ }^{29}$ Bibliographies show that scholars of Roman law in Poland

czyk, 'Usucapio'. Rzymskie pochodzenie wspótczesnej instytucji zasiedzenia ['Usucapio.' Roman origins of the modern institution of usucaption], Gdańsk 2016; G. Blicharz, Udziat państwa w spadku. Rzymska myśl prawna w perspektywie prawnoporównawczej [The state's share in the inheritance. Roman legal thought in legal comparative perspective], Bielsko-Biała 2016.

${ }^{24} \mathrm{http} / / /$ bibliografie.wpia.uw.edu.pl/bprp/ [accessed on 28 December 2019]. However, the Polish law and history bibliography available on the Internet has not been updated since 2014: http:// bibliografia.ihp.wpia.uw.edu.pl/ [accessed on 28 December 2019].

${ }^{25}$ K. Kolańczyk, Stanislas Wróblewski, le "Papinien Polonais" et son "Précis de cours de droit romain" [in:] Studi in onore di Edoardo Volterra, vol. IV, Naples 1971, pp. 329-342.

26 S. Wróblewski, Potrzeby nauki polskiej a prawo rzymskie [The needs of Polish science and Roman law], "Nauka Polska" 1919, No. 2, p. 264.

27 Ibidem.

${ }^{28}$ Ibidem, p. 262.

${ }^{29}$ Ibidem, p. 266. 
have not given up studying issues which can be described as universal for world science. Fifty years later, Henryk Kupiszewski claimed that "the Polish science of Roman law encompasses almost all fields of its study." 30 With that in mind, he considered that it was necessary: to develop research into Roman rights in rem as it would be useful for the theory of modern private law; the development of tout court research into ancient Rome and Greek poleis system of government in association with historians; participation in the integration of research into antiquity. ${ }^{31}$ Shortly after the Autumn of Nations in Poland in 1990, Henryk Kupiszewski in the last months of his life critically evaluated the reduction of requirements for Roman law exams at Polish faculties of law. He contrasted it with the publishing of comprehensive Roman law handbooks in Italy, Germany, and Austria. It was his considered opinion that rigorism in this area is necessary to adjust Polish legal order to European standards. ${ }^{32}$ Kupiszewski indicated in his "scientific last will" what was key for Roman law research and teaching: understanding Roman law as a foundation of private law in Europe, a phenomenon of culture which conveys ethical values; perceiving the role of Roman law for the development of legal argumentation; understanding Roman law as a common denominator of legal orders in Eastern and Western Europe. ${ }^{33}$ A chapter by Marek Kuryłowicz, which was published in the same book, shows that political changes in Poland were accompanied by doubts regarding to the future of the study of Roman law in this country. He pointed out the following as a remedy to the menace of the downfall of the science of Roman law: a comprehensive presentation of the history of Roman law in Poland; publishing papers to popularize Roman law, and, "probably the most important task," preparing a Roman law handbook for academics and legal practitioners engaged in present-day private law. ${ }^{34}$ Bibliographies show that there is no simple correlation between these recommendations and publications by Polish authors on Roman law. The influence of Roman law on Polish law and legal culture is a subject matter which has been dealt with by researchers of Roman law in Poland for 100 years. However, it has not dominated this field of research to such an extent as was postulated by Wróblewski. Up until now, a comprehensive presentation of the history of Roman law in Poland has not been prepared. Polish Romanists have not given up to publishing papers - mainly in Polish - dealing

${ }^{30}$ H. Kupiszewski, Prawo rzymskie w 25-leciu PRL ze szczególnym uwzględnieniem ostatnich lat [Roman law in the 25 years of the Polish People's Republic with special consideration paid to the last years], "Sprawozdania z prac naukowych Wydziału Nauk Społecznych PAN" 1970, No. 13, issues $3-4$, p. 68.

${ }_{31}$ H. Kupiszewski, Prawo rzymskie... [Roman law...], pp. 86-87.

${ }^{32}$ H. Kupiszewski, Droit romain..., p. 172.

${ }^{33}$ Ibidem, pp. 172-173.

${ }^{34}$ M. Kuryłowicz, Aufstieg..., p. 181. 
with similar issues to the ones their foreign colleagues tackle. Nevertheless, a comprehensive study of the law of property, which was postulated 50 years ago by Henryk Kupiszewski, has not been written yet. ${ }^{35}$ Five years ago, Marek Kuryłowicz expressed his hope that work on the Roman law handbook, which has been postulated for decades, would accelerate and it would serve as an introduction to modern private law. ${ }^{36}$ The number of publications on public Roman law has grown significantly in the last few decades. However, despite H. Kupiszewski's recommendations, only a minor part of them results from the research cooperation with tout court historians or classicists. ${ }^{37}$ There is no discernible tendency to associate a growth in the number of private and criminal Roman law books which would be accompanied by an ambitious drive to present the results of their research in foreign languages. ${ }^{38}$ Consequently, one can claim that the topics of Polish publications on Roman law in the past one hundred years are not a realization of some general scientific strategy. In my opinion, one also cannot talk about the domination of some method of researching ancient Roman law and its history until the present day in Poland. None of the proposals, which can be considered the leading ones in the field of Roman law research in Poland, have determinated a course of research for all, or even for the majority of, faculties of law. The choice of research fields and research methods is made locally. Sometimes there is even a large diversity in this choice at a particular faculty of law. In the case of certain universities, one can notice the prevalence of specific fields of research between the end of the $20^{\text {th }}$ century and the first decades of the $21^{\text {st }}$ century. ${ }^{39}$ However, only reading the bibliographies can give a clear image of the diversity of topics. The bibliographies portray the differences pertaining to the aims and methods of re-

${ }^{35}$ M. Zabłocka, Romanistyka polska w pierwszym... [Roman law studies in Poland in the first...], p. 55 .

${ }^{36}$ M. Kuryłowicz, 'Illotis manibus'. Henryk Kupiszewski i wspótczesne dyskusje romanistyczne w Polsce ['Illotis manibus.' Henryk Kupiszewski and modern Romance discussions in Poland], “Zeszyty Prawnicze UKSW" 2015, issue 2, p. 105.

37 See e.g.: H. Kowalski, M. Kuryłowicz (eds.), 'Contra leges et bonos mores'. Przestęstwa obyczajowe w starożytnej Grecji i Rzymie ['Contra leges et bonos mores.' Crimes against morality in ancient Greece and Rome], Lublin 2005; A. Dębiński, H. Kowalski, M. Kuryłowicz (eds.), 'Salus rei publicae suprema lex'. Ochrona interesów państwa w prawie karnym starożytnej Grecji i Rzy$m u$ ['Salus rei publicae suprema lex.' Protection of state interest in criminal law of ancient Greece and Rome], Lublin 2007; K. Amielańczyk, A. Dębiński, D. Słapek (eds.), Ochrona bezpieczeństwa i porzadku publicznego w prawie rzymskim [Protection of security and public order in Roman law], Lublin 2010.

38 The following papers are exceptions in this context: A. Tarwacka, Romans and Pirates. Legal Perspective, Warsaw 2009; J. Wiewiorowski, The Judiciary of Diocesan Vicars in the Late Roman Empire, Poznań 2015.

${ }^{39}$ Cf. M. Zabłocka, Romanistyka polska w pierwszym... [Roman law studies in Poland in the first...], p. 192. 
searching Roman law. The aims of this article do not require a precise mapping of this diversity; they do not even allow for it. However, one needs to mention that the latest Polish Roman law bibliographies contain short evaluations based on the quantitative criteria of the number of publications, the number of Roman law $\mathrm{PhDs}$, and habilitations, and the number of professor nominations for Romanists. On that basis, Maria Zabłocka came to the conclusion in 2013 that Poland is one of the leading countries in the field of Roman law research. ${ }^{40}$ Four years later, she wrote: "it seems that lean years for the science of Roman law have arrived in Poland." ${ }^{41}$ Naturally, every attempt for a general evaluation requires adopting some general criteria. The recommendations formulated one hundred years ago by Wróblewski distinguished themselves with a clear connection with the idea of rationality of academic teaching and financing of research. However, Stanisław Wróblewski adopted the assumption that Roman law will not lose "one of the top spots" in the curriculum of law studies in Poland "for many years to come." ${ }^{42}$ At the same time, he predicted that Roman law "will not attract Polish scholars very much." ${ }^{43}$ These two prima facie discrepant opinions were based on the belief that the state will provide financing for "robust Roman law specialists" to ensure good education for lawyers. According to Wróblewski's opinion, this was to make the development of Roman law studies in Poland possible. ${ }^{44}$ Later statements about the situation and the main tasks of the research of Roman law in Poland do not express the belief in the rationality of the financing system of Polish science anymore. What is more, the political changes of 1990 brought - as was demonstrated above - statements which contained anxiety about the future of the Roman law in Poland. The formalized system of evaluating and financing of scientific research, which has been developed in Poland since 2010, is openly named as the danger to the research of Roman law. ${ }^{45}$ A profound reconstruction of higher education and science in Poland in 2018 was justified by the unsatisfactory quality of academic teaching and the low level of significance of the research carried out in Poland on the world class.$^{46}$ In my opinion, the formula which directs attention to important issues for Polish science of Roman law in the time of profound changes in science

${ }^{40}$ Ibidem, p. 192.

${ }^{41}$ M. Zabłocka, Gorsze lata... [Worse years...], p. 131.

${ }^{42}$ S. Wróblewski, Potrzeby nauki polskiej... [The needs of Polish science...], p. 264.

${ }^{43}$ Ibidem.

${ }^{44}$ Ibidem, p. 265.

${ }^{45}$ M. Zabłocka, Romanistyka polska w pierwszym... [Roman law studies in Poland in the first...], p. 191; M. Kuryłowicz, a review of: M. Jońca, "Prawo rzymskie" [Roman law]. Marginalia, Lublin 2012, "Czasopismo Prawno-Historyczne" [CPH, Journal of Legal and Historical Sciences] 2013, Vol. LXV, issue 2, p. 446.

${ }^{46}$ Uzasadnienie projektu ustawy Prawo o szkolnictwie wyższym i nauce [Justification of the Higher education and science bill], pp. 3, 7. 
in Poland is concentrated on two issues: if and how the rationality of legal education is an inspiration for publications concerning Roman law? What is the relation between the traditional understanding of internationalization in the science of Roman law and the statutory system of evaluation of the significance of research in the world, which is now adopted in Poland?

\section{RESEARCH AND TEACHING OF ROMAN LAW - A BENEFICIARY OR A VICTIM OF THE NEW SCIENCE POLICY IN POLAND?}

After a cursory glance, one can claim that there is a similarity between the justification of stated in the legislative process concerning the Higher education Act of 2018, namely, the pursuit of improving the quality of education that students receive, and the much earlier statements by S. Wróblewski and H. Kupiszewski who claimed that the high level of Roman law lectures is for the benefit of the quality of legal education in Poland. Emphasizing the importance of international cooperation of Polish Romanists can be considered to be a similar aim to the one of the Polish lawmaker, which improves the position of Polish institutions in global universities rankings. The reality is more complex however. It is connected with the two aforementioned questions. The first one is connected with the thesis by S. Wróblewski pertaining to the significance of Roman law for the high standard of legal education.

\subsection{Is the rationality of legal education an inspiration for publications on roman law and, if so, how?}

There are not many publications dealing with the issue concerning the rationality of legal education in Poland. ${ }^{47}$ Decisions pertaining to the model of legal studies currently rest on the respective universities. I believe that the two types of publications are of special importance for the continued presence of Roman law in the curriculum of law studies in Poland. First of all, translations which make it possible

${ }^{47}$ F. Zoll, Jaka szkoła prawa? [What school of law?], Łódź 2004; B. Sitek, P. Polaczuk, Reforma szkolnictwa wyższego. Kształcenie prawników w Polsce na tle doświadczeń innych państw europejskich [Higher education reform. Education of lawyers in Poland in the context of the experiences of other European countries], "Forum Prawnicze" 2012, Vol. 13, No. 5, p. 10; P. Machnikowski, Szkoty bezrobotnych prawników? [Schools of unemployed lawyers?], "Na Wokandzie" 2013, Vol. 18, No. 4, p. 48; W. Dajczak, Kontekst reformy studiów prawniczych [The context of legal studies reform], "Ruch Prawniczy, Ekonomiczny i Socjologiczny" [Journal of Law, Economics and Sociology] 2013, Vol. 75, issue 4, p. 9 et seq.; M. Gutowski, P. Kardas, Nadprodukcja niedouczonych prawników [Overproduction of ignorant lawyers], "Dziennik. Gazeta Prawna" $30^{\text {th }}$ of August 2017, https://prawo.gazetaprawna.pl/artykuly/1067344,nadprodukcja-niedouczonych-prawnikow. $\mathrm{html}$ [accessed on 9 January 2020]. 
to show source examples to students who do not know Latin. Secondly, publications which can be considered an attempt to create a Roman law handbook for academics and legal practitioners of private law, which has been anticipated for decades, as well as papers which contribute to the preparation of such a handbook.

\subsubsection{Translations of roman legal texts into polish}

One of the instruments of the deep changes in the financing of Polish science was the foundation of the National Programme of the Development of the Humanities by the Minister of Science and Higher Education in November $2010 .^{48}$ Acquiring the financing for the translation and publication of the Digest of Justinian was a success of the team led by Tomasz Palmirski. ${ }^{49}$ Its entirety was published between 2013 and 2017. The need to introduce this source into the circulation of modern humanities also in Polish was pinpointed as the main rationale behind the project. The importance of the Digests as a current source of skills of legal reasoning was emphasized in the preface to the translation. ${ }^{50}$ If one shares the my view that teaching this way of thinking lies at the heart of legal education, then this publication can support the thesis concerning the usefulness of Roman law in the good education of lawyers. The translation can be a basis for an innovative use of Roman law to develop students' soft skills. ${ }^{51}$ Students can access Roman legal sources during Roman law classes despite according to statistics, only about $2 \%$ of Polish pupils are taught Latin in high school nowadays. ${ }^{52}$ In this context, one can postulate a thesis that the translation of the Digests was the most important result of the tendency to broaden the access Polish readers have to Roman sources of law, which is visible in Poland since the beginning of the $21^{\text {st }}$ century. In the past twenty years, there were also published translations of such texts as: The Law of the Twelve Tables, ${ }^{53}$ Diocletian's Edict

\footnotetext{
${ }^{48}$ A communiqué by the Minister of Science and Higher Education issued on the $5^{\text {th }}$ of November 2010, "Monitor Polski" [Polish Monitor], No. 86, item 1014.

49 The previously translated basic sources of Roman law which were translated into Polish in their entirety are Gaius' Institutions [Gaius. Instytucje [Gaius. Institutions], transl. C. Kunderewicz, Warsaw 1982; Gai Institutiones. Instytucje Gaiusa [Gai Institutiones. Gaius' Institutions], transl. W. Rozwadowski, Poznań 2003] and Justinian's Institutions (Instytucje Justyniania [Justinian's Institutions], transl. C. Kunderewicz, Warsaw 1986).

${ }^{50}$ T. Palmirski et al. (eds.), Digestia Iustiniani. Digesta Justyniańskie. Tekst i przekład [Digestia Iustiniani. Justinian's Digests. The original text and translation], vol. 1, Cracow 2013, p. 50.

${ }^{51}$ W. Mossakowski, An Attempt at an Evaluation of Editorial Work in Translated Sources of Roman Law in Contemporary Poland, "Comparative Law Review" 2014, No. 17, p. 142.

52 A. Krzemińska, Ciszej z ta taciną! [Would you keep it down with the Latin!], "Polityka" $4^{\text {th }}$ of April 2017, p. 64. Polish Philological Society is taking steps to prevent the exclusion of Latin from Polish schools. See: http://www.ptf.edu.pl/lacina-w-sejmie/ [accessed on 2 January 2020].

${ }_{53}$ M. Zabłocka, J. Zabłocki, Ustawa XII Tablic. Tekst-tlumaczenie-objaśnienia [The Law of the Twelve Tables. The text - the translation - explanations], Warsaw 2003.
} 
on Maximum Prices, ${ }^{54}$ Lex Coloniae Genetivae Iuliae seu Ursonensis, and lex Irnitiana, ${ }^{55}$ Mosaicarum et Romanarum legum collation, ${ }^{56}$ Ulpiani liber singularis regularum, ${ }^{57}$ The Edictum Theodorici. ${ }^{58}$ There are also regularly published translations of selected short fragments of sources concerning Roman law and legal practice..$^{59}$ The more translations like these are available, the fewer obstacles there will be to show law students or lawyers the rationes decidendi what can support their practical skills. It is crucial, however, if and how such use of old law will be connected with the modern legal problems. Consequently, what has been said in Poland for decades should not be surprising, namely, a Roman law handbook needs to be prepared for academics and private law practitioners.

\subsubsection{The idea of a roman law handbook for academics and private law practitioners}

The idea to publish a Roman law handbook for academics and private law practitioners has been repeated in Poland for a long time ${ }^{60}$ One of the pioneers of this idea was Kazimierz Kolańczyk who introduced footnotes referring readers to contemporary Polish law into his Roman law handbook..$^{61}$ This handbook has been published multiple times. At the end of the $20^{\text {th }}$ century, it was labelled "the best post-war handbook for the teaching of Roman law." ${ }^{62}$ In 2015, Marek Kuryłowicz noticed "a certain attempt" pointing in the direction of the idea of a Roman law handbook as an introduction to modern private law. It was the book entitled Prawo rzymskie. U podstaw prawa prywatnego [Roman law. At the Foundations of

${ }^{54}$ Edictum Diocletiani de pretiis rerum venalium. Edykt Dioklecjana o cenach towarów wystawionych na sprzedaż [Edictum Diocletiani de pretiis rerum venalium. Diocletian's Edict Concerning the Price of Goods for sale], transl. A. Barańska, P. Barański, P. Janiszewski, Poznań 2007.

${ }^{55}$ Lex Coloniae Genetivae Iuliae seu Ursonensis $i$ Lex Irnitiana. Ustawy municypalne antycznego Rzymu. Tekst, thumaczenie i komentarz [Lex Coloniae Genetivae Iuliae seu Ursonensis i Lex Irnitiana. Municipal acts of ancient Rome. The text, translation, and commentary], transl. B. Sitek, Poznań 2008.

${ }^{56}$ Mosaicarum et Romanarum legum collatio. Zbiór prawa Mojżeszowego i rzymskiego [Mosaicarum et Romanarum legum collatio. A collection of the Mosaic law and Roman law], transl. A. Dębiński, Lublin 2011.

${ }^{57}$ Ulpiani liber singularis regularum. Pojedyncza księga regut Ulpiana [Ulpiani liber singularis regularum. A single book of rules by Ulpian], transl. A. Dębiński, K. Burczak, Lublin 2016.

${ }^{58}$ Edykt Króla Teodoryka [The edict of king Theodoric], transl. A. Caba, M. Ożóg, Cracow 2018.

${ }^{59}$ M. Zabłocka, Romanistyka polska $w$ pierwszym... [Roman law studies in Poland in the first...], pp. 25-28; eadem, Gorsze lata... [Worse years...], pp. 133-135.

${ }^{60}$ K. Kolańczyk, Nowy podręcznik rzymskiego prawa prywatnego [New coursebook of Roman private law], CPH 1965, Vol. XVII, issue 1, p. 254.

${ }^{61}$ K. Kolańczyk, Prawo rzymskie [Roman law], Warsaw 1973.

${ }^{62}$ J. Kodrębski, Najnowsze polskie podręczniki prawa rzymskiego [The newest Roman law handbooks in Poland], CPH 1995, Vol. XLVII, issue 1-2, p. 241. 
Private Law]. ${ }^{63}$ This handbook was published for the first time in 2009 and three revised editions have been published since then. ${ }^{64}$ The foundation of all these editions is the idea, that that Roman law should no longer be presented as a system of legal institutions described in a similar manner to the applicable law. Roman law is mainly treated, above all, as the legacy of legal thought. It allows us to illustrate how law reflects values and what those values might be from the legal perspective. ${ }^{65}$ The revisions made to the subsequent editions consisted in extending such solutions based on antique sources of Roman law, ius commune texts and solutions adopted in the drafting and amending of the civil codes in France, Germany, and Poland. The more significant difficulty in the use of such a handbook by students we explained with the claim that "the job market does not need the poorly educated lawyers." ${ }^{\prime 66}$ The new handbook has provoked a lively discussion in Poland. It received eight reviews. ${ }^{67}$ The next editions of the handbook were based on the analysis of the reviews which are partly divergent. The understanding of the nature of the present day changes in private law is a controversy of fundamental importance. Does one attach significance to the process of decodification and, if so, what is its significance ${ }^{68}$ And, as a consequence, what kind of approach to Roman law is useful for students, academics, and legal practitioners today? ${ }^{69}$ It is possible that this handbook will provoke other authors to publish innovative books referring to Roman law in a manner which would present the usefulness of Roman law for law students and lawyers today. In any event, the use of Roman law as an important element of the discussions, which have been held to this day, about the problems of private law adopted in our handbook has become an impulse to the authors of a few monographs in recent years. By placing this trend in the context of deep changes in the Polish science, one needs to say that some of them were supported by the prestigious "Diamond grant" (Diamentowy grant) programme which was founded by the Minister of Science and Higher Education in October $2011 .^{70}$ No more than 100 outstanding young researchers from all fields of science receive full financial backing of their doctoral projects for four years. Within this framework, there were published methodologically coherent books

${ }^{63}$ M. Kuryłowicz, Illotis manibus..., p. 105, fn. 11.

${ }^{64}$ W. Dajczak, T. Giaro, F. Longchamps de Berier, Prawo rzymskie. U podstaw prawa prywatnego [Roman law. At the foundations of private law], Warsaw 2009' ${ }^{1}, 2014^{2}, 2018^{3}$.

${ }^{65}$ Ibidem, $2018^{3}$, pp. $30-31$.

${ }^{66}$ Ibidem, p. 25.

${ }^{67}$ Ibidem, p. 26.

68 J.H. Merryman, The Civil Law Tradition. An Introduction to the Legal Systems of Western Europe and Latin America, Stanford 1985, p. 151.

69 M. Kuryłowicz, Illotis manibus..., p. 105, fn. 11.

${ }^{70}$ A communiqué by the Minister of Science and Higher Education issued on the $27^{\text {th }}$ of October 2011 ("Monitor Polski” [The Polish Monitor], issue 98, item 999). 
on the new Roman law handbook. Namely, The state's share in inheritances. Roman legal thought in a comparative legal perspective, ${ }^{71}$ The enforceability of agreements. The sources of the freedom of contract in canon law and modern controversies surrounding its foundations. ${ }^{72}$ Last but not least, thanks to the publication of the Czech version of the handbook ${ }^{73}$ and thanks to its modified parts in foreign languages, the method employed within can be also evaluated by readers who read in Czech, English, ${ }^{74}$ and Spanish. ${ }^{75}$ Only time will tell if and to what extent such research into Roman law can lead to the dissemination of its image as a subject which elevates the quality of legal education. However, I believe that this argument, which was used 100 years ago by S. Wróblewski, can rationally ensure the continued presence of Roman law in the curriculum of Polish faculties of law in the future. In the current model of research evaluation in Poland the international impact of Polish studies of Roman law could support the reputation and financing of academic institutions which carry out said research. For these reasons, it must lead to a confrontation between the traditional understanding of internationalization in the study of Roman law and the criteria of internationalization adopted in the reform of Polish science of 2018. Nextly, the article tackles the second of the questions above.

\subsection{What is the relation between the traditional understanding of internationalization in the study of roman law and the understanding of world - class research according to the new polish law on higher education and science?}

Henryk Kupiszewski put a point entitled "the place of the Polish science of Roman law in the world" in his evaluation of the research into Roman law conducted in Poland, which was published 50 years ago. He adopted the following as the premises of of international recognition of research activities: the publishing of the articles by Polish authors in leading journals such as "Zeitschrift der Savigny - Stiftung für Rechtsgeschichte" (ZSS), "Romanistische Abteilung," "Iura. Rivista intenazionale di diritto romano e antico," "Revue Internationale des Droits de L'Antiquité" (RIDA), "Rivista Italiana per le Scienze Giuridiche" (RISC) and in foreign Festschrift's; publishing books abroad by several Polish authors; regu-

${ }^{71}$ A doctoral thesis by G. Blicharz defended on the $27^{\text {th }}$ of June 2016.

${ }^{72}$ A doctoral thesis by P. Alexandrowicz defended on the $26^{\text {th }}$ of November 2019.

${ }^{73}$ W. Dajczak, T. Giaro, F. Longchamps de Berier, P. Dostalik, Právo řimské. Základy soukromého práva, Olomouc 2013.

${ }^{74}$ F. Longchamps de Berier, Law of Succession. Roman Legal Framework and Comparative Law Perspective, Warsaw 2011.

${ }^{75}$ W. Dajczak, Derecho Romano de obligaciones. Continuación y modificationes en la tradición juridica europea, Santiago de Compostela 2018. 
lating the statute and appointing an international scientific council of the "Journal of Juristic Papyrology;" the participation of Poles in foreign conferences on Roman law, direct contact with foreign Romanists, mainly from Italy. ${ }^{76}$ The stability of this way of understanding of the international position is shown by later statements of other Polish Romanists. Therefore let's look at this perspective on the last 20 years of Roman law in Poland.

\subsubsection{The international position of polish publications on roman law - the traditional perspective}

political and economic changes in Poland after 1990 have caused that the largest increase in international cooperation among Polish Romanists who are interested in such cooperation pertains to research trips, travelling as guest lecturers and going to conferences abroad. Detailed statistics are neither possible nor necessary. However, there are some spectacular examples. H. Kupiszewski wrote the following words in 1969: "it would be highly desirable to have at least one Polish researcher of Roman law take part in the Société d'histoire des droits de 1'Antiquité congress each year." ${ }^{\text {"77 }}$ Polish Romanists have regularly presented their papers at this congress since the beginning of the $90 \mathrm{~s}$. One might treat Polish presence at this congress as a qualitative change as it was organized by the Chair of Roman Law of the Jagiellonian University. The $72^{\text {nd }}$ Session of the SIHDA Congress ocurred in Cracow in $2018 .{ }^{78}$ An outstanding achievement in this form of international scientific cooperation was also the organization of the $27^{\text {th }}$ International Congress of Papyrology with the participation of the Faculty of Law in Warsaw in 2013. ${ }^{79}$ The strong international recognizability of Polish legal papyrology, which was built by Rafał Taubenschlag, is strengthened by the "Journal of Juristic Papyrology," which is available in open access. ${ }^{80}$ It ranks among A class legal journals on the list of the National Agency for the Evaluation of Universities and Research Institutes in Italy. ${ }^{81}$ The list, which is prepared by experts, allows one - it is probably the most adequate representation of the views of academic lawyers in continental Europe - to determine which journals are considered prestigious in the European science of Roman law and legal history. On this basis, "the most important journals" which were enumerated by H. Kupiszewski

${ }^{76}$ H. Kupiszewski, Prawo rzymskie... [Roman law...], pp. 67-68.

${ }^{77}$ Ibidem, p. 68.

${ }^{78}$ https://www.law.uj.edu.pl/users/kprz/index.php/sihda-krakow-2018 [accessed on 3 January 2020].

79 http://www.papyrocongress2013.wpia.uw.edu.pl/ [accessed on 3 January 2020].

${ }^{80} \mathrm{http}: / /$ bazhum.muzhp.pl/czasopismo/181/ [accessed on 3 January 2020].

${ }^{81} \mathrm{http} / /$ www.anvur.it/wp-content/uploads/2019/03/Area-12-Classe-A-II-quadrimestre-ASN-2018-2020-1.pdf [accessed on 3 January 2020]. 
should be supplemented with: "Bulletino dell'Istituto di Diritto Romano 'Vittorio Scialoja"" (BIDR), "Comparative Legal History" (CLH), "Forum Historiae Iuris" (FHI), "Historia et Ius" (HI), "Index. Quaderni Camerti di Studi Romanistici" (Index), "Labeo," "Rechgtsgeschichte" (RG), "Revue Historique de Droit Français et Étranger (RDH), "Seminarios Complutenses de Derecho Romano" (SCDR), "Studia et Documenta Historiae et Iuris" (SDHI), "The American Journal of Legal History" (AJLH), "The Journal of Legal History" (JLH), "Tijdschrift voor Rechtsgeschidenis" (TR). On the basis of the electronic bibliography of papers about Roman law by Polish authors with minor supplements, one can observe that the number of publications by Polish authors in these journals in the past twenty years is not big. It is visibly smaller in the majority of cases than it was before the year $2000 .{ }^{82}$ Hence, there is no correlation between the number of publications by Polish authors in the indicated journals in the $21^{\text {st }}$ century and the increase in the number of people employed at Polish chairs of Roman law and the large growth of their mobility in this time. The places where Polish authors publish their papers on Roman law and on the civil law tradition abroad are more dispersed than they were in the previous century. This means that publishing papers outside these journals is frequently easier or more important. Both of these motivations can also be applied to publishing in other foreign scientific journals. In any case, there is no positive correlation between the evaluation system of the international impact of research introduced in Poland in 2010 and the publishing of articles in the indicated journals by Polish authors. This gives rise to specific questions: can the changes in the evaluation of the quality of scientific research in Poland from 2018 result in an increase in the interest of Polish authors in publishing in the indicated magazines? Or maybe the Polish culture of publishing papers on Roman law in the $21^{\text {st }}$ century is not adequate to these changes?

\subsubsection{The international position of polish publications on roman law - the perspective of the present polish evaluation system of the quality of research}

the changes in the evaluation of the quality of research in 2010 were already based on giving great importance to bibliometric criteria. The new Polish law on higher education of 2018 further developed and strengthened the importance of the bibliometric criteria in the evaluation of research. This also pertains to legal

${ }^{82}$ This is how the situation looks in case of the enumerated journals: ZSS: after $2000-1$, before 2000 - 18; Iura: before 2000 - 6, after 2000 - 3; RIDA: after 2000 - 19, before 2000 - 20; BIDR: after $2000-0$, before $2000-11$; CLH - 0; FHI - 0; HI - 0; Index: after 2000: 6; before 2000 - 22; Labeo: after 2000 - 1, before 2000 - 9; RG - after 2000 - 1 (it has been published since 2002); RDH: after $2000-2$, before $2000-0$; SCDR: after $2000-3$, before $2000-0$; SDHI: after $2000-0$, before 2000 - 7; AJLH - 0; JLH - 1, before 2000 - 0; TR: after 2000 - 2, before $2000-1$. 
sciences. Publishing articles in the journals indexed in the Scopus database and in the Science Citation Index Expanded the Social Sciences Citation Index, the Arts \& Humanities Citation Index, and the Emerging Sources Citation Index base is currently of crucial importance for acquiring a higher rating for a particular discipline of science at a particular university ${ }^{83}$ Only a few of the journals which are indexed in these bases and are considered prestigious for scholars of Roman law and the history of law are among the journals mentioned above. Furthermore, due to their relatively low Impact Factor, these few journals also do not award a distinctive number of points in the Polish formalized evaluation of research. ${ }^{84}$ This situation is not changed by the fact that some Polish Romanists' regularly have their chapters published in books published abroad. In recent years, several Polish authors have published their monographs on Roman law in foreign languages ${ }^{85}$ Italian researches show that experts in Roman law consider the prestige of a book or a chapter that is strictly connected with a publishing series. The publisher takes the last place in this ranking of criteria which are important for a book's prestige. These studies also show the belief in the importance of a book's reviews. ${ }^{86}$ However, publishing reviews of Polish books on Roman law abroad is less frequent than it once was. It concentrates today on books published by Polish authors in foreign languages. Publishing reviews in Poland of Polish as well as of foreign books on Roman law still ocurrs, however, with a smaller intensity than even in the beginning of the $21^{\text {st }}$ century. I believe that it needs to be emphasized because reviews in Poland have no significance in the formalized evaluation of an author's research activities. They are not relevant in the evaluation of a book they pertain to in spite of the fact that experience shows an obvious disparity between evaluations in reviews and evaluations based on the bibliometric criteria. ${ }^{87}$ In the Polish system of evaluation of science, a monograph's grade depends only on the

${ }^{83}$ Regulation $\S 6$ by the Minister of Science and Higher Education of the $7^{\text {th }}$ November 2018 on preparing lists of publishers of scientific monographs as well as of scientific magazines and reviewed papers after international conference (Journal of Laws 2018, item 2152).

${ }^{84}$ On a scale from 20 to 200 points, it is: ZSS - 70, CLH - 20, AJLH - 70, JLH - 100, TR - 40.

${ }^{85}$ Besides the mentioned papers on public Roman law, one can point to: T. Giaro, Römische Rechtswahrheiten. Ein Gedankenexperiment, Frankfurt am Main 2007; A. Plisecka, 'Tabula picta'. Aspetti giuridici del lavoro pittorico in Roma antica, Padua 2011; W. Dajczak, The Nature of Contract in Reasoning of Civilian Jurists, Poznań 2012; A. Kacprzak, Tra logica e giurisprudenza. Argumentum a simili nei Topici di Cicierone, Warsaw 2012; F. Longchamps de Berier, L'abuso del diritto nell'esperienza del privato romano, Turin 2013.

${ }^{86}$ G. Peruginelli, S. Faro, T. Agnoloni, A Survey on Legal Research Monograph Evaluation in Italy [in:] A. Bonaccorsi (ed.), The Evaluation of Research in Social Sciences and Humanities, Berlin - Heidelberg 2018, p. 225.

87 W. Dajczak, a review of: A. Burdese, "Recensioni e commenti. Sessant'anni di letture romanistiche”, Padua 2009, volume 1, pages VIII + 787, volume 2, pages VIII + 778, CPH 2011, Vol. LXIII, issue 1, pp. 465-468. 
publishing house. There are 36 publishing houses with high rank ( $2^{\text {nd }}$ level) on the official list. American and English publishing houses dominate this list. There is not a single publishing house from Poland or from any of the Romance countries on the list. The number of publications determined in this manner by Polish authors on Roman law is negligible. ${ }^{88}$ Polish publishing houses dominate the list with lower ratings ( $1^{\text {st }}$ level). The Polish list encompasses very few publishing houses from the Romance countries. There are no publishers on the list which are traditionally publishing books which are recognizable in the science of Roman law around the world such as: CEDAM, Giappichelli, or Jovene. This short remark already allows one to give an answer to the two aforementioned questions. In the first place, the Polish system of evaluation of research rather discourages Polish authors from publishing in the majority of journals, which are considered the most prestigious ones in the science of Roman law and the history of law by Italian experts. Secondly, the presently dominating culture of publishing on Roman law by Polish authors in foreign languages is fundamentally different from the statutory criteria of scientific excellence of research. Approaching these criteria would not only mean giving up publishing in numerous foreign journals which are important from the point of view of the science of Roman law and the history of law. It would also have to mean a departure from book publications in Italy, Spain, Austria, Switzerland, and in numerous German publishing houses. Consequently, it would be a departure from the style of publishing which still dominates in the European science of Roman law. The significant differences between the traditional understanding of the international importance of research into Roman law and the Polish system of evaluating the importance of research in the world are clearly visible. Therefore, it is difficult to expect the results of Polish research into Roman law to become an argument for their endurance because they significantly serve to enhance the reputation and financing of an academic institution where the said research is conducted.

\section{CONCLUSIONS}

In the past one hundred years, it has been differently understood what is the most important thing for the endurance of the teaching and research of Roman law in Poland. One year after regaining independence, Stanisław Wróblewski connected it with the usefulness of Roman law in order to provide legal education on a high level. And fifty years later, halfway into the dominance of the Commu-

${ }^{88}$ A. Kacprzak, Rhetoric and Roman Law [in:] C. Ando, P. Du Plessis, K.Tuori (eds.), Oxford Handbook of Roman Law, Oxford 2016, pp. 200-213; J. Urbanik, Husband and Wife [in:] C. Ando, P. Du Plessis, K.Tuori (eds.), Oxford Handbook..., pp. 473-486. 
nist Party in Poland, Henryk Kupiszewski emphasized that the good preparation of the younger generation of Polish researchers of Roman law will serve their expansion in accordance with international, first and foremost, Italian standards of the study of Roman law. ${ }^{89}$ The changes in the Polish higher education system during the first 20 years after the political transition of 1990 were characterized by a large increase in the number of students, $\mathrm{PhD}$ students, and employees at higher education institutions. Appropriately for this trend, an increase in the number of publications and in the number of academic promotions was emphasized in the evaluation of the Polish studies of Roman law in the first two decades of the $21^{\text {st }}$ century. ${ }^{90}$ The future of this field of science is connected with "young people [...] who finish or begin writing their PhDs in Roman law and European legal tradition." ${ }^{91}$ However, according to the rules pertaining to the evaluation of research in Poland which are in force since 2018, academic promotions are irrelevant for the evaluation. The number of publications is also irrelevant. ${ }^{92}$ If the endurance of the study of Roman law is to be connected with the new bibliometric criteria of a publication's evaluation, then publishing abroad would require a departure from the culture of publishing which not only dominates the science of Roman law but also the science of law in continental Europe in general. Awarding supremacy to bibliometric evaluation would support the integration of research into Roman law with ancient history or with classics. ${ }^{93}$ This is an uncertain path. A large increase in the number of publications pertaining to Roman public law did not lead to a quantitatively expanded and formalized cooperation between Roman law historians and historians of antiquity or classicists. There was also no strategic cooperation with the lawyers of modern public law. In the framework of formalized evaluation of Polish science, such institutional coming together could pave the way for moving Roman law out of the legal sciences. As a consequence, the the future of the Roman law at Polish faculties of law is a hard issue. The answer to the query, what is crucial for the endurance of Roman law in Poland, is uncertain and subjective. In my opinion, the best rationale for the presence of the Roman law in Poland was pointed out by Stanisław Wróblewski one hundred years ago. It is confirmed by

${ }^{89}$ H. Kupiszewski, Prawo rzymskie... [Roman law...], p. 68.

${ }_{90}$ M. Zabłocka, Romanistyka polska w pierwszym... [Roman law studies in Poland in the first...], p. 9; eadem, Gorsze lata... [Worse years...], p. 132 et seq.

${ }_{91}$ M. Zabłocka, Gorsze lata... [Worse years...], p. 132.

${ }_{92}$ As part of the planned evaluation of a particular discipline of science which takes place every four years, one will be able to take into account no more than four and no less than two publications of one scholar.

${ }^{93}$ According to the current system of science evaluation in Poland, a large number of points is awarded by certain historical or philological magazines, e.g.: "Byzantinische Zeitschrift" - 200 points; "Zeitschrift für Antikes Christentum" - 140 points, "Gnomon. Kritische Zeitschrift für die gesamte Klassische Altertumswissenschaft" - 100 points. 
the view, which has been repeated for decades, which states the need for publishing a handbook of Roman law for academics and private law practitioners. The handbook of Roman law. At the foundations of private law is undoubtedly making strides in the attempt to make a change in the use of Roman law in the legal education in Poland. ${ }^{94}$ Deep changes in the law, technology and culture do not allow one to just repeat Wróblewski's opinion. Lawyers receive different general education to the one from one hundred years ago. Law works in a different context now than it did back then. New ideas pertaining to the nature and function of private law are formulated. ${ }^{95}$ Today, noticing the changes inspires one to combine Wróblewski's opinion with the following question: do we want to continue the understanding of the nature of private law which is core of the civil law tradition and, if so, to what extent? Granting a fundamental role to bibliometric criteria in the evaluation of legal sciences is equal to terminating the traditional understanding of the rationality of legal educations and the legal studies. The defence of this tradition as well as the necessary improvement of the quality of legal education can be realized by academic lawyers presenting innovative standards of legal education and research. The experience of how the continuation of the civil law tradition combines with changes can be a source of inspiration here. I believe that the study of Roman law in Poland will endure if the majority of academic lawyers adhere to the continuation of the civil law tradition and acknowledge that Roman law rationally serves this continuation in the education of lawyers'. Roman law needs to communicate with other areas of law. Hovewer onus is on modern lawyers too. The practical sense of the civil law tradition is a part of today's fundamental dispute about what is Western civilization and how it is to be understood. For this reason, I perceive the main task of the science of Roman law in Poland differently than it was perceived one hundred years ago by S. Wróblewski and more radically than H. Kupiszewski and M. Kuryłowicz several decades ago. In my opinion the study of Roman law should show the usefulness of Roman law in the discussion about the basic problems of private law and legal methods today. Publishing such papers by Polish authors in the same places as their colleagues from Italy, Spain, France, or Germany will serve to develop critical debates about law in Europe. Furthermore, it will strengthen the authority of such publications in Polish legal science. Moreover, translating the Code of Justinian and Justinian's Novels into Polish will also be beneficial for the endurance of the Roman law tradition in the Polish culture.

94 See fn 62.

${ }^{95}$ See, e.g.: M.W. Hesselink, The New European Private Law. Essays on the Future of Private Law in Europe, The Hague - London - New York 2002; K. Barker, K. Fairweather, R. Grantham (eds.), Private Law in the $21^{\text {st }}$ Century, Oxford - Portland 2017. 
The Higher eduction Act of 2018 introduced far-reaching changes and, for this reason, it can reinvigorate the discussion if and to what extent Polish science and academic education are changing for the better. The experience gathered in the past decade makes it highly probable that further amendments will be introduced into the Polish law on higher education and science. One of the designers of the changes of Polish higher education which have been introduced since 2010 finished his comprehensive sociological analysis of these changes by saying: "Polish chances lay in an old Latin maxim, plus ratio quam vis, which puts mind over strength." ${ }^{.96}$ The same maxim was the topic of the Société d'histoire des droits de l'Antiquité congress, which ocurred in Cracow in 2018. Time will tell if an understanding of rationality can be reached between people who create the higher education policy in Poland, the majority of Polish academic lawyers, and Polish scholars of Roman law.

${ }^{96}$ D. Antonowicz, Między sita... [Between the power...], p. 365. 